\title{
Wykorzystanie kontrolera Kinect do interakcji z użytkownikiem w VR
}

\author{
Przemysław Samoń*, Tomasz Szymczyk \\ Politechnika Lubelska, Instytut Informatyki, Nadbystrzycka 36B, 20-618 Lublin, Polska
}

Streszczenie. W artykule przedstawiono autorską metodę badania reakcji człowieka na dźwięk przestrzenny. Wykorzystano ogólnodostępne urządzenia takie jak: sensor Kinect, zestaw dźwięku przestrzennego Creative. Opracowano metodę badawczą, metodę analizy oraz niezbędne scenariusze badawcze. Ponadto zaproponowano dwie ankiety: przed i po badaniu. Następnie opracowano wyniki badań, a na ich podstawie sformułowano wnioski.

Slowa kluczowe: sensor Kinect; akwizycja ruchu; przetwarzanie danych

*Autor do korespondencji.

Adres e-mail: przemyslawsamonal@gmail.com

\section{Using Kinect controller for interacting with user in VR}

\author{
Przemysław Samoń*, Tomasz Szymczyk \\ Institute of Computer Science, Lublin University of Technology, Nadbystrzycka 36B, 20-618 Lublin, Poland
}

\begin{abstract}
The article presents the author's method of studying human reaction to spatial sound. Public devices such as: Kinect sensor, Creative surround sound set were used. A research method, method of analysis and necessary research scenarios were developed. In addition, two questionnaires were proposed: before and after the study. Next, the results of the research were developed and the conclusions were formulated on their basis.
\end{abstract}

Keywords: sensor Kinect; acquiring traffic; data processing

${ }^{*}$ Corresponding author.

E-mail address: przemyslawsamonal@gmail.com

\section{Wstęp}

Popularność sprzętu do przechwytywania ruchu rośnie $\mathrm{z}$ roku na rok. Trafia on w coraz szersze grono odbiorców szukających nowego rodzaju rozrywki. Za sprawą niskiej, przystępnej ceny oraz szerokiego kanału dystrybucji trafia on do coraz szerszego grona odbiorców, szukających nowego rodzaju rozrywki. Popularny Kinect jest innowacyjnym, bezdotykowym interfejsem służącym głównie rozrywce. Przeze swoje zaawansowane możliwości autorzy wykorzystują go do badania ruchu.

Przeprowadzone badania zostały wykonane w celu sprawdzenia, czy interaktywnym dźwiękiem przestrzennym możemy wpływać na człowieka i na jego zachowanie. Dodatkowym aspektem jest też fakt czy dostępne na rynku narzędzia, którymi posługujemy się na co dzień, pozwolą zbadać takie oddziaływanie. Badanie pozwoli zweryfikować także analizę poprawności działania napisanego algorytmu, który przetwarza dane o ruchu.

Badania zostały przeprowadzone na dwudziestu osobach w podobnym wieku, $\mathrm{z}$ różnych grup zainteresowań. Ponad połowa zadeklarowała fakt, że grała w gry komputerowe o tematyce wojennej.

Dla celów badawczych opracowano aplikacje w następujących językach:

- $\mathrm{CH}$,

- Javascript.
Skrypty zostały zaimplementowane w silniku Unity. Główne skrypty oprogramowania stworzone zostały w technologii C\#. Jest to w pełni obiektowym język stworzonym przez Andersa Hejlsberga na potrzeby .NET w latach 1998-2001 [1]. Środowisko Unity jest narzędziem do tworzenia gier komputerowych dwuwymiarowych i trójwymiarowych. Posiada także własny sklep, z którego pobierzemy niezbędne zasoby dla projektów.

Przed pomiarami osoby badane wypełniły ankiety przed badaniem o chorobach i problemach które dyskwalifikują do kontynuowania badań. Każdy scenariusz posiadał oddzielny plik wynikowy wraz z analizą wideo.

\section{Akwizycja ruchu, czyli przechwytywanie ruchu trójwymiarowego.}

Przechwytywanie ruchu (Motion Capture) jest procesem polegającym na rejestrowaniu ruchu obiektów lub ludzi. Znalazł on swoje zastosowanie w armii, rozrywce, sporcie oraz medycynie, stosowany jest również przy uwierzytelnianiu widzenia komputerowego i w robotyce. W branży filmowej i gier wideo odnosi się do zapisywania ruchu aktorów i używania uzyskanych informacji do tworzenia animacji postaci w 2D lub 3D. Gdy proces skupia się na ruchach twarzy, palców, albo przechwytuje delikatne zmiany w mimice, często określa się go mianem przechwytywania performance (ang. performance capture). W wielu dziedzinach przechwytywanie ruchu często nazywane jest śledzeniem ruchu (ang. motiontracking), jednak w branży filmowej i gier, termin ten odnosi się bardziej do techniki zwanej 
matchmoving, umożliwiającej realistyczne wprowadzenie obiektów grafiki komputerowej do nagranego już materiału filmowego [2].

Rekonstrukcja ruchu w systemach Motion Capture polega na odtworzeniu orientacji przestrzennej ruchu ciała aktora. Jest to równoznaczne ze znalezieniem obrotów dla każdej z kości, dla których możliwie najlepiej markery wirtualne odpowiadają markerom rzeczywistym, minimalizując przy tym przyjęty wskaźnik błędu pomiędzy markerami [3]. Markery rzeczywiste odwzorowują realne punkty w przestrzeni, która jest pokazana w konkretnym czasie. Na owe punkty możemy nałożyć algorytm, który analizuje odległości odpowiednich punktów między sobą (tych, które powinny zostać ze sobą połączone, by stworzyć model człowieka). Pozwala nam to zwizualizować, np. w środowisku Unity, jak wyglądają połączone punkty, które zostały odczytane. Jeżeli sensor Kinect źle odczyta daną klatkę animacji, zauważymy odchylenie któregoś $\mathrm{z}$ punktów. $\mathrm{Na}$ rysunku 1 widzimy wizualizację punktową modelu, a także nałożone połączenia w postaci figur geometrycznych.
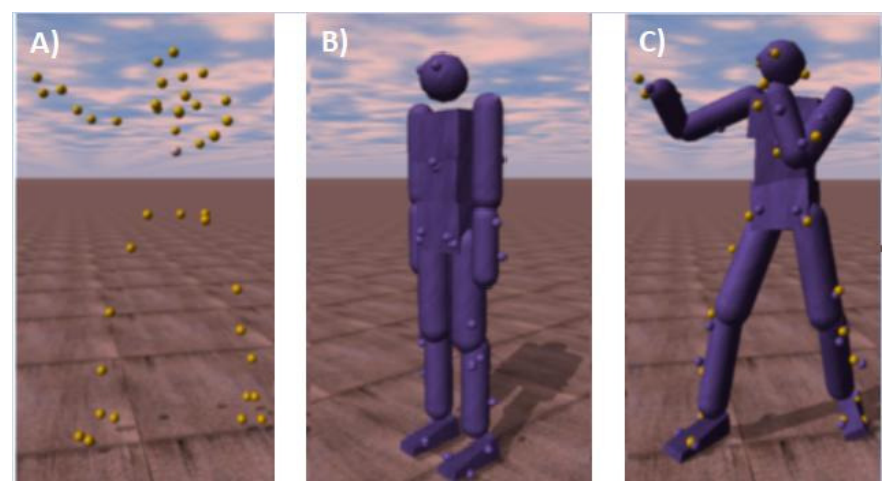

Rys. 1. Wizualizacja sylwetki człowieka a) Wizualizacja modelu za pomocą kropek, b) Wizualizacja modelu za pomocą brył, c) Wizualizacja modelu za pomocą brył i kropek

\section{Przegląd literatury}

Wirtualna rzeczywistość jest stosunkowo innowacyjną technologią, która rozwinęła się bardzo dynamicznie w ostatnich latach. Jest używana w wielu aspektach naszego życia jak np. edukacja, rozrywka i medycyna. Coraz więcej prac naukowych i artykułów odnosi się swoimi badaniami do wirtualnej rzeczywistości. Spowodowane jest to dużą możliwością odtworzenia warunków naturalnych nawet w ekstremalnych przypadkach. Dzięki temu można zwizualizować dowolny scenariusz w prawie każdym miejscu i każdych warunkach. Daje to nieograniczone możliwości połączeń scenariuszy.

Według analizy Matta Matthewsa sensor Kinect Xbox 360 [4] stał się bardzo dochodowym biznesem dla producenta. Za niewielki koszt możemy dostać nowoczesną technologię. Wyniki sprzedaży pokazane na wykresie samego sensora w przeciągu 2 lat wynoszą około 20 milionów egzemplarzy. Co dało firmie Microsoft przychód na poziomie kilku milionów dolarów miesięcznie. Były to rekordowe wyniki sprzedaży w porównaniu do konkurencyjnych urządzeń dostępnych na rynku. Kinect był przełomową technologią, którą ludzie pokochali ze względu na wygodę użytkowania (brak jakichkolwiek dodatkowych kontrolerów, jakie trzeba używać za pomocą dłoni).
Artykuł opisuje wytwarzanie oprogramowania poprzez ruch sensora Kinect wraz z okularami bluetooth [5] oraz informuje o technicznej budowie sensora Kinect. Rejestracja ruchu odbywa się za pomocą czujnika Kinect. Emiter podczerwieni emituje promienie podczerwone, które odbijają z obiektów do wykrycia przez czujnik głębokości IR. Wynikowy videostream jest przechwytywany przez czujnik koloru. Mamy 3 strumienie danych: kolorowy strumień, strumień audio i strumień głębi. Mapa głębi przechowuje odległość obiektu i wartość dla każdego piksela. W oparciu o technologię wykrywania, głębokości obraz graficzny i współrzędne dla każdego punktu uzyskujemy połączenie szkieletowe. Informacje te możemy wykorzystać dla naszej aplikacji do badań zachowania i lęków człowieka oraz wpłynięcie na jego podświadomość i psychikę.

W artykule o Akrofobii Erick Suyanto [6] opisuje podejście do badania strachu poprzez wirtualną rzeczywistość. Zadaniem badanego było przejście przez linę lub most, który znajdował się na bardzo dużej wysokości i nie był do końca stabilny. Według badań poziom nasilania się akrofobii można zmniejszyć za pomocą aplikacji. Wewnątrz ludzie mogą w bezpieczny sposób zmierzyć się ze strachem w swoim umyśle. Dodane np. prawdziwe liny (obiekty trzymane w dłoniach) pomagają zwiększać poczucie realności środowiska. Autorzy wspominają, że pomaga to także zmniejszyć skutki strachu. Takie badania pozwalały ludziom zniwelować strach przed spadaniem. Z kolei to pokazało, że wirtualna rzeczywistość wpływa tak samo bardzo na zmysł wzroku i słuchu jak realny świat.

Dzięki firmie Microsoft otrzymaliśmy dostęp do oprogramowania sensora Kinect [7]. Pozwoliło to na szeroki rozwój w dziedzinach badań. Programiści projektują scenariusze, dzięki czemu można stworzyć bezpieczne warunki testowe. Pozwoliło to leczyć ludzi z różnych fobii a, także badać jego zachowanie.

Artykuł Fotini Patrona opisuje zachowania człowieka podczas przeprowadzonego badania. Weryfikuje on czy badanie należy powtórzyć, gdy badany nie pokazuje przypuszczalnych oznak bojaźni. Jeżeli przeprowadzony scenariusz zostanie uznany jako odbiegający od faktycznego stanu, zostanie powtórzony. Powoduje to urealnienie wyników lub weryfikację poprawności przewidywanego scenariusza [8].

\section{Badania}

W celu przeprowadzenia badań opracowano aplikację dedykowaną dla środowiska Unity w językach C\# oraz Javascript.

\section{1. Środowisko badawcze}

Pomieszczenie, w którym zostały przeprowadzone badania, było wytłumione, o wymiarach 5 metrów x 3 metry, ze sztucznym oświetleniem. Do dźwięku przestrzennego wykorzystano model głośników Logitech Speaker System Z323 wraz z subwooferem. Osoba badania znajdowała się w centralnej części pokoju, jak pokazano na rysunku 6.1. Sala zawierała komputer posiadający środowisko Unity w wersji 5.6 oraz oprogramowanie do obsługi Kinecta w wersji 1.8. Posiada procesor Intel i7 trzeciej generacji oraz 16GB pamięci RAM. Komputer połączony był z głośnikami i odtwarzał dźwięk przestrzenny. Osoba badana miała zawiązane oczy 
i nie był wymagany jest dodatkowy sprzęt do przeprowadzenia badania.

\subsection{Metoda badawcza}

Przed badaniem osoba badana została poinformowana o scenariuszu badawczym, jaki zostanie przeprowadzony. Następnie badany zostaje ustawiony na środku pomieszczenia oraz następuje kalibracja sensora, która polega na teście odczytu czy Kinect wykrył osobę badaną i czy cała znajduje się W zasięgu. Podczas trwania scenariusza osoba badana miała zakryte oczy. Przez cały czas trwania badania, do aplikacji dostarczone były dane odczytywane z ruchu badanego.

\subsection{Schemat przeprowadzenia badania}

Badanie zostało przeprowadzone w następujących krokach:

1) Przeprowadzenie wywiadu z osobą badaną.

2) Odtwarzanie muzyki relaksacyjnej.

3) Kalibracja sprzętu dostosowana do badanego.

4) Scenariusz wilków.

5) Scenariusz strzałów.

6) Scenariusz nadjeżdżającego pociągu.

7) Przeprowadzenie ankiety po scenariuszach.

\subsection{Scenariusze badawcze}

Głównym badanym elementem był wpływ dźwięku przestrzennego na osoby badane $i$ odwzorowanie ich zachowania podczas scenariusza. Zostały przeprowadzone 2 scenariusze, które zawierają różne opcje przypadków. Ankieta pozwoliła uzyskać dane na temat subiektywnego odbioru własnego zachowania uczestników podczas scenariusza z wilkiem. Scenariusze zostały poprzedzone ankietą sprawdzającą możliwości przystąpienia do badania. Zostały dołączone dodatkowe pytania o problemy z sercem, ADHD oraz poziom gestykulacji podczas rozmowy. Umożliwi to lepiej skalibrować ruch oraz wyciąć część ruchów, które nie powinny być zapisane jako faktyczna reakcja na scenariusz.

Pierwszym scenariuszem jest symulacja sytuacji badanego w ciemnym lesie, gdy zbliża się niebezpieczne zwierzę. Badanie sprawdziło, czy człowiek jest w stanie uspokoić się w sytuacji stresowej. Osoba badana została zaprowadzona w pomieszczeniu na odpowiednie miejsce przed sensor Kinect. Na początku nastąpiła konfiguracja urządzenia poprzez test widoczności szkieletu na ekranie komputera. Następnie badany wykonał kilka ruchów testowych dla ustalenia odpowiedniej pozycji. Podczas przeprowadzania badania niezbędne było założenie opaski na oczy. Po wykonaniu tych elementów nastąpiło rozpoczęcie badania. Badanie będzie trwało około 2 minut gdzie zostaje przeprowadzony atak wilka. Sprawdzono zachowanie gdy nasze zachowanie nie ma wpływu na zachowanie wilka.

Drugim scenariuszem sprawdzono zachowanie człowieka w sytuacji zamieszanie. Do tego celu wykorzystano zamieszanie przypominające strzelnicę. Obiekt za plecami strzela wystrzałem przed nas a następnie wraz na osobę badano leci seria strzał z karabinu maszynowego. Strzały zostają wystrzelone tuż przed osobą badaną w losowych miejscach.
Ostatnim scenariuszem sprawdzono zachowanie człowieka podczas symulacji zbliżania się w jego kierunku dużego, niebezpiecznego obiektu. Obiektem w symulacji był rozpędzony pociąg, zbliżający się z prawej strony, wprost na badanego. Warunki badania i kroki zostały przeprowadzone jak w scenariuszu pierwszym. W tym scenariuszu osoba badana nie znała dokładnego przebiegu badania. Badanie sprawdziło strach na głośny obiekt poruszający się centralnie na człowieka.

Wszystkie scenariusze dostarczyły danych o ruchu badanego. Do badań zostały dołączone nagrania wideo, które pozwoliły zweryfikować dane o ruchu tam, gdzie sensor nieprawidłowo zinterpretował dane.

\section{Wyniki badań}

Wyniki badań zostały przeprowadzone na 20-osobowej grupie badawczej. Większość z osób zadeklarowała, że gra $\mathrm{W}$ gry komputerowe o tematyce wojennej. Badania zaprezentowane poniżej skupione zostały na podzieleniu człowieka na części ciała i sprawdzenie którymi kończynami poruszamy w danej sytuacji zagrożenia najczęściej.

Po przeprowadzeniu scenariuszy i przeanalizowania danych przygotowano wykresy ruchu dla poszczególnych scen w każdej kolejnej sekundzie danego badania. Wszystkie wyniki zostały zweryfikowane pod względem poprawnościbłędne wskazania Kinect zostały odrzucone. Za ruch, danej części ciała, uznano dodatni wektor ruchu: długość, kąt obrotu, przesunięcie, obliczony przez Unity 3D.

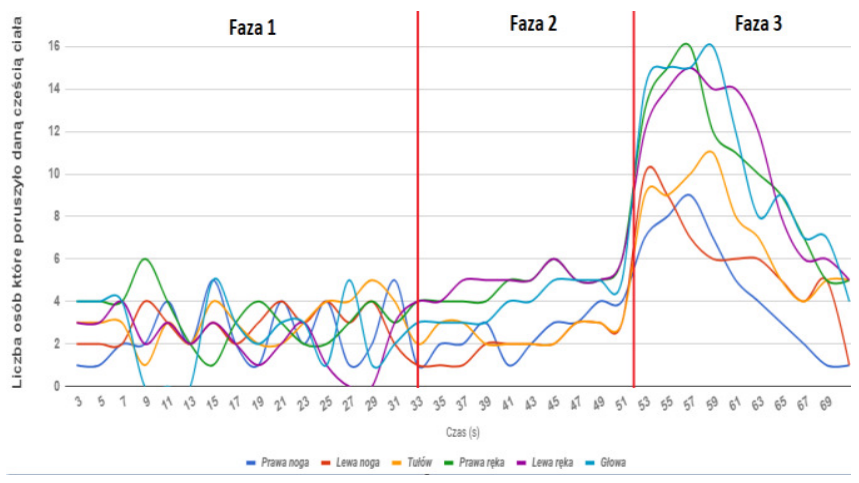

Rys. 2. Wykres ruchu poszczególnych części ciała w kolejnych sekundach scenariusza $\mathrm{z}$ wilkiem

Na rysunku 2 przedstawiono zbiorczo ruch daną kończyną. Faza 1 to ekspozycja osoby badanej na dźwięk biegającego daleko od niej wilka. Często osoba badana nie rozpoznawała jeszcze zagrożenia. Faza 2 to początek uświadamiania sobie zagrożenia. „Wirtualny agresor” wyraźnie zbliża się i atakuje. Towarzyszy temu wzrost amplitudy dźwięku i zmiana sampla na inny - groźne szczekanie i warczenie. Atak następuje około 1 sekundy przed wystąpieniem fazy 3 . W fazie 3 osoba badana jest wyraźnie przestraszona i porusza się- stara się zasłonić rękami głowę.

Rysunek 3 prezentuje zbiorczo ruch kończyn osób badanych w scenariuszu 2 . W fazie 1 osoba badana słyszy dźwięk przeładowywanej za nią broni. Porusza się zupełnie swobodnie bez udziału żadnych niepokojących bodźców. W fazie 2 następuje oddanie strzału przez "wirtualną osobę" zza pleców badanej. Wyraźnie widoczne jest „drgnięcie”, 
„skok" wywołane przestrachem. Zauważyć można także pewne „ochłonięcie”, spadek emocji tuż przed fazą 3 - padł niespodziewanie strzał, nastąpił ruch, i uspokojenie. W fazie 3 osoba badana wyraźnie słyszy ostrzał z karabinu maszynowego $\mathrm{z}$ linii horyzontu w jej kierunku. Strzały są oddawane w kierunku ,wirtualnej osoby” zza jej pleców, ale to właśnie osoba badana znalazła się na linii strzału. Taka sytuacja wywołuje panikę co wyraźnie widać na wykresie (rys. 3) w fazie 3.

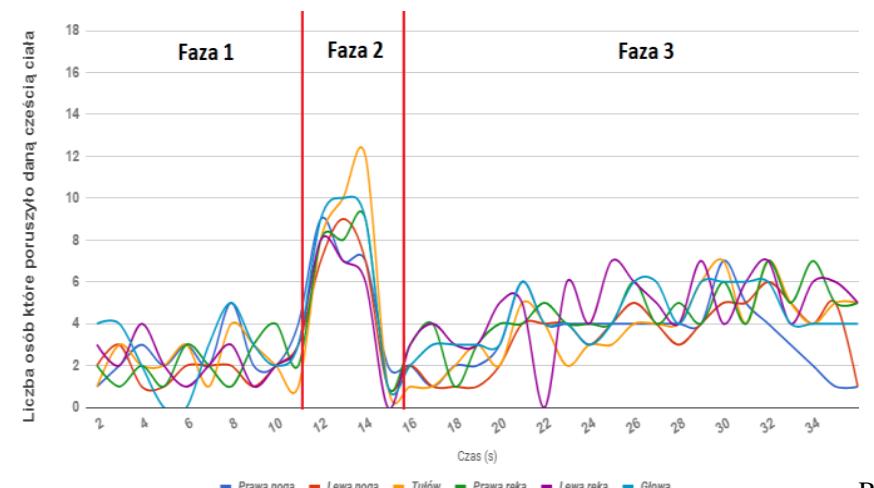

ys. 3. Wykres ruchu poszczególnych części ciała w kolejnych sekundach scenariusza ze strzałami

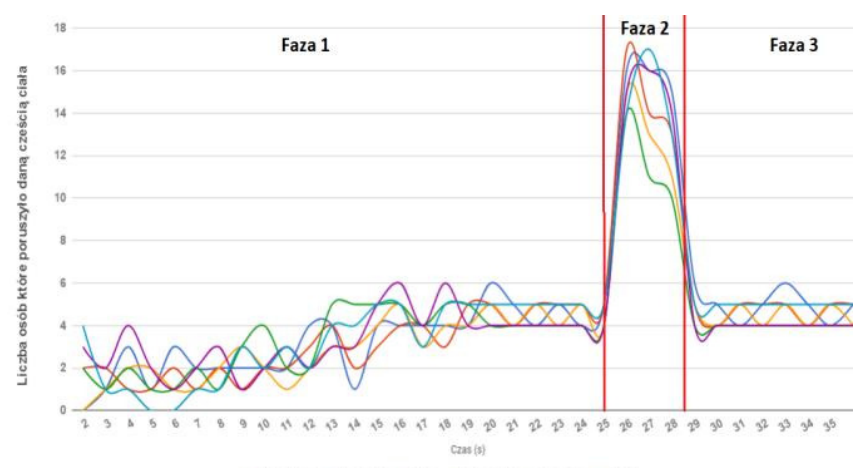

Rys. 4. Wykres ruchu poszczególnych części ciała w kolejnych sekundach scenariusza z pociągiem

Scenariusz $\mathrm{z}$ pociągiem przedstawiony na rysunku 4 wzbudził najwięcej emocji. Wirtualny pociąg: leniwie, ale konsekwentnie zbliża się do osoby badanej. Na powyższym rysunku 4 obrazuje to faza 1 . Można w niej zaobserwować ogólne ruchy kończynami. Faza 2 to szybki trwający mniej niż 2 sekundy przejazd pociągu tuż przy badanym. Powoduje to wyraźny „dyskomfort” i próbę ,uskoczenia”. Widoczna faza 3 to czas uspokojenia się badanego po silnym bodźcu lękowym.

Rysunek 5, 6 i 7 pokazują jakimi częściami ciała poruszały osoby badane podczas scenariuszy. We wszystkich wykresach przeważają ruchy rąk. Świadczy to o najszybciej reakcji na sytuację. Osoby badane miały zakryte oczy, co sprawiało, że nie wiedziały, w którą stronę uniknąć sytuacji zagrożenia. W rzeczywistym świecie ludzie reagują także górnymi partiami ciała. Pokazuje to, że przygotowane scenariusze wpłynęły na psychikę badanych. Ruch głowy na rysunku 5 i rysunku 6 wskazuje, że osoby badane próbowały zasłonić ją w jakiś sposób. Mózg w sytuacji zagrożenia próbuje przekazać odpowiednie sygnały ciału by, uniknąć jakichkolwiek obrażeń.

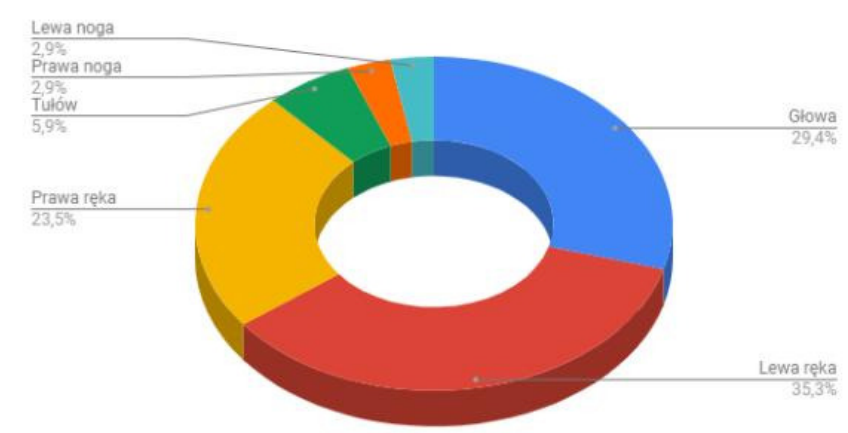

Rys. 5. Wykres używalności poszczególnych partii ciała w scenariuszu $\mathrm{z}$ wilkami

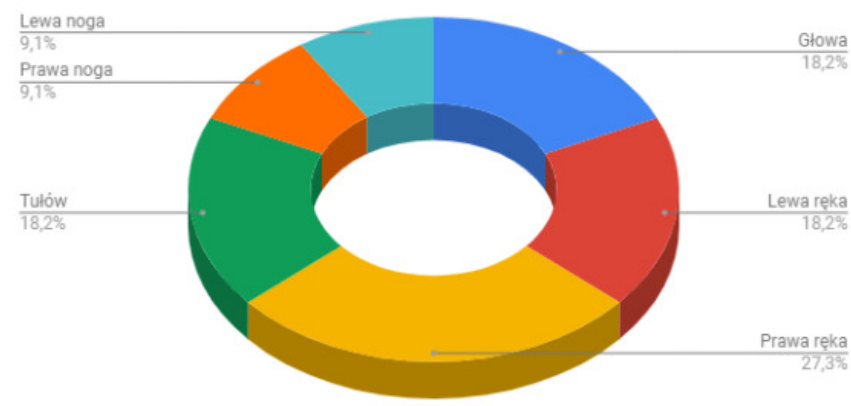

Rys. 6. Wykres używalności poszczególnych partii ciała w scenariuszu ze strzałami

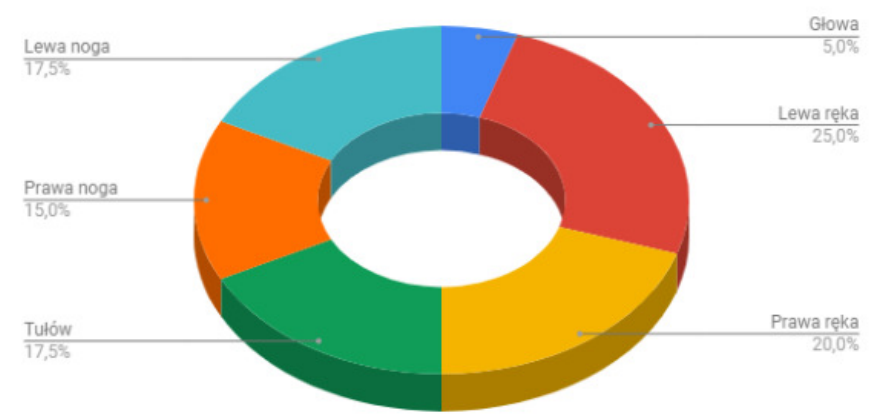

Rys. 7. Wykres używalności poszczególnych partii ciała $\mathrm{w}$ scenariuszu $\mathrm{z}$ pociągiem

\section{Wnioski}

Problematyka poruszona w tym artykule jest popularnym tematem do badań nad zachowaniem człowieka w warunkach stresowych. Przed badaniami spodziewano się, że najmniej prawdopodobne scenariusze (strzelanina na strzelnicy lub atak wilka) wywołają najsilniejsze emocje - najsilniejszy ruch. Wyniki badań pokazały jednak coś innego. Sytuacja najbardziej prawdopodobna - stanie na torach kolejowych (scenariusz 3- pociąg) wywołała największy lęk u wszystkich badanych. Ponadto sam przejazd pociągu trwający zaledwie 1,75 sekundy wywołał reakcję trwającą pomiędzy 25 -tą a 28,5 sekundy, czyli 3,5 sekundy. Na tej podstawie można wyznaczyć inercję mięśni człowieka. Pociąg „uderzył” w badanych dokładnie w 25 sekundzie projekcji. Nadjeżdżał on z kierunku: prawy przód dla osób badanych. Spowodowało 
Journal of Computer Sciences Institute

to naturalną chęć „odskoczenia”, co widać na ruchu kończyn dolnych rysunek 7 . Na pozostałych rysunkach (rys. 5 i rys. 6) ruch nóg wynosi od 2,9 do około 9,1 procent ogólnego ruchu całego ciała.

Podczas badań nie wystąiły problemy zdrowotne. Wszystkie 20 osób badanych zostały przebadane wszystkimi zaplanowanymi (trzema) scenariuszami. Żadna $\mathrm{z}$ osób nie przerwała badania i nikt nie skarżył się na żadne objawy uboczne po zakończeniu.

\section{Literatura}

[1] Pańczyk B., Badurowicz M., Programowanie obiektowe - Język C\#, Politechnika Lubelska, 2013.

[2] https://www.mocap.pl/blog/motion-capture-przechwytywanieruchu.

[3] Pięciak T., Pawłowski R. Wizualizacja ruchu człowieka ( Motion Capture ), Inżynierowie dla Biologii i Medycyny : kwartalnik wykładowców i studentów inżynierii biomedycznej : ISSN 189709149 - 2009 nr 5, 22-27.
[4] https://www.gamasutra.com/view/news/172666/Analysis_Wher e_do_Kinect_sales_go_from_here.php.

[5] Iliukhin V.N., Mitkovskii K.B. , Bizyanova D.A., Akopyan A.A.: The Development of Motion Capture System Based on Kinect Sensor and Bluetooth-Gloves, Procedia Engineering 2017, 506-513.

[6] Marchelino Suyanto E., Angkasa D., Turuga H., SutoyoR.:Overcome Acrophobia with the Help of Virtual Reality and Kinect Technology, Procedia Computer Science 2017, 476-483.

[7] https://www.pcworld.pl/news/Microsoft-Kinect-zawsze-iwszedzie, $383881 . h t m l$.

[8] Patrona F., Chatzitofis A., Zarpalas D., Daras P. : Motion analysis: Action detection, recognition and evaluation based on motion capture data, Patern Recognition April 2018, 612-622. 